\title{
Effect of Different Drying Methods on Micronutrient Content of Selected Green Leafy Vegetables
}

\author{
Sushmita Khatoniar ${ }^{1 *}$, Mridula Saikia Barooah $^{1}$ and Mamoni Das ${ }^{2}$ \\ ${ }^{1}$ Community Science, Krishi Vigyan Kendra, Lakhimpur, Assam-787032, India \\ ${ }^{2}$ Department of Food Science and Nutrition, College of Community Science, Assam \\ Agricultural University, Jorhat, Assam-785013, India \\ *Corresponding author
}

\section{A B S T R A C T}

The present study intends to investigate micronutrient content of six commonly consumed greens namely Amaranthus spinosus, Chenopodium album, Spinaciaoleracea, Phyllanthus amarus, Talinum triangulare and Ludwigia adscendens after dehydration by using four different drying methods, i.e. sun drying, shade drying, cabinet dryer drying and

\section{Keywords}

Micronutrients,

Greens,

Dehydration,

Drying methods

\section{Article Info}

Accepted:

12 June 2019

Available Online:

10 July 2019 microwave oven drying. Among the nutritional parameters, total mineral content, iron, calcium, potassium, phosphorous and ascorbic acid content was found highest in cabinet dryer dried samples, followed by microwave dried samples. Iron content was highest in dehydrated Amaranthus spinosus $(86.80 \mathrm{mg} / 100 \mathrm{~g})$ followed by Phyllanthus amarus $(32.50$ $\mathrm{mg} / 100 \mathrm{~g})$, Talinum triangulare $(28.20 \mathrm{mg} / 100 \mathrm{~g})$ and Chenopodium album (25.30 $\mathrm{mg} / 100 \mathrm{~g})$. Calcium content was found highest in dehydrated Amaranthus spinosus (2920.38 mg/100g) followed by Talinum triangulare $(1206.67 \mathrm{mg} / 100 \mathrm{~g})$ and Chenopodium album $(1142.50 \mathrm{mg} / 100 \mathrm{~g})$. The phosphorous content was highest in Talinum triangulare $(546.56 \mathrm{mg} / 100 \mathrm{~g})$ and Spinacia oleracea contained highest potassium content $(2526.30$ $\mathrm{mg} / 100 \mathrm{~g}$ ) in cabinet dried samples. Microwave oven dried Talinum triangulare contained highest amount of ascorbic acid $(13.96 \mathrm{mg} / 100 \mathrm{~g})$. Thus it can be concluded that the mineral content of all of the selected greens became concentrated after dehydration. These dehydrated leaves have good rehydration capacity for incorporation into various products to reduce micronutrient deficiency.

\section{Introduction}

India is blessed with an array of leafy vegetables of which some are cultivated many are gathered. Green leafy vegetables represent an excellent component of the habitual diet in the tropical and temperate countries like India. They add variety to a monotonous diet, have an alternative taste, attractive in appearance and contribute a pleasing aroma and a natural colour (Rajeshwari, 2010). Green leafy vegetables are highly perishable because of their high moisture content and the presence of natural enzymes (Nwufo, 1994). Other structural characteristics, such as a large surface area result in loss of moisture and wilting. Post-harvest handling alters the shelf life of such vegetables to a great extent. 
During their season, when greens are available in abundance, poor handling procedures and lack of proper storage facilities result in heavy losses. Conservation of greens to reduce losses and to make them available for consumption in the off-season is a matter that needs consideration (Fathima et al., 2001). Dehydration is a simple user friendly, traditional technology which converts the vegetables in to crisp form, reducing in size to facilitate the utility throughout the year. Another added advantage of this method is that the dried vegetable powder can be then easily incorporate in to different traditional recipes (Gupta and Prakash, 2011). Dehydration makes green leafy vegetables a concentrated source of vitamins and minerals and thus they become a very suitable "natural fortificant" (Joshi and Mathur, 2010). To increase consumption of green leafy vegetables in a convenient way, an attempt was made to dehydrate few locally available greens of Assam to increase their shelf life and thus reducing wastage.

\section{Materials and Methods}

Six commonly available green leafy vegetables were selected and procured from the local market of Jorhat city, Assam. Selection of the green leafy vegetables was done on the basis of their availability and which are commonly grown in this region. After collection the edible portions were cleaned by removing the infested and diseased portion. The leaves were thoroughly washed in running tap-water and finally in distilled water and the surface moisture was removed. The samples were then dried using four drying methods, namely sun drying, shade drying, cabinet dryer drying and microwave oven drying. Moisture and ash was estimated by using standard method (AOAC 2000), iron content was determined according to Wong's method described by Ranganna (1986) and phosphorous content was determined according to the Fiske and Row's method described by Ranganna (1986) by using spectrophotometer (Model No. 2513). Calcium and potassium was determined by using flame photometer (Model MM III) according to the method A.O.A.C. (1984). Ascorbic acid was determined by volumetric method.

\section{Results and Discussion}

\section{Effect of moisture content of the greens after dehydration}

Moisture content of the dried product is an indicator of efficiency of dehydration. The moisture content of green leafy vegetables under different drying methods are presented in Table 1, which decreases up to $80-90 \%$ on drying. Microwave drying resulted in lower level of moisture content (3.64-4.55 g/100g) than other drying methods. Shade dried green leafy vegetables retained highest amount of moisture (5.34-6.76 g/100g) which may be due to high humidity content in air of this region. Significant difference was found in moisture content of sun and shade dried green leafy vegetables $(\mathrm{p}<0.05)$. Microwave dried Phyllanthus amarus contained lowest amount of moisture $(3.64 \mathrm{~g} / 100 \mathrm{~g})$ and shade dried Spinacia oleracea showed highest moisture content $(6.76 \mathrm{~g} / 100 \mathrm{~g})$ among all drying methods.

Study conducted by Kushwaha (2012) on comparative effect of cabinet and microwave drying on nutritional quality of onion stalks reported that moisture content of microwave dried onion stalks resulted with lower moisture content $(5.98 \mathrm{~g} / 100 \mathrm{~g})$ than cabinet drying (6.83 g/100g). This denotes the superiority of latter over the former in maintaining uniform temperature, low relative humidity, and faster removal of moisture as the electromagnetic waves produced were efficient in agitating the moisture molecules 
and removing them through the tissues without causing much damage.

\section{Effect of ash content of the greens after dehydration}

Ash content indicates the mineral content of food substances. In the present study, the ash content increases on dehydration as the moisture from the green leafy vegetables are reduced. Cabinet dried Amaranthus spinosus ranked highest ash content of $16.83 \mathrm{~g} / 100 \mathrm{~g}$ and sun dried Ludwigia adscendens showed lowest ash content of $7.78 \mathrm{~g} / 100 \mathrm{~g}$. The ash content of sun dried green leafy vegetables ranged between $7.78-15.67 \mathrm{~g} / 100 \mathrm{~g}$ whereas ash content of shade dried, cabinet dried and microwave dried green leafy vegetables were in the range of $8.04-16.44 \mathrm{~g} / 100 \mathrm{~g}, 8.76$ $16.83 \mathrm{~g} / 100 \mathrm{~g}$ and 8.57 - $16.62 \mathrm{~g} / 100 \mathrm{~g}$ respectively. Ukegbu and Okereke (2013) studied effect of sun and solar drying on the nutrient composition of Amaranthus hybridus, Telferia occidentalis and Hibiscus esculentus. Results revealed that solar dried vegetables had significantly higher $(\mathrm{p}<0.05)$ ash content than sun dried and fresh vegetables. Ash content of Amaranthus hybridus was 8.02 $\mathrm{g} / 100 \mathrm{~g}$ (solar dried) and $7.55 \mathrm{~g} / 100 \mathrm{~g}$ (sun dried), Telferia occidentalis $20.11 \mathrm{~g} / 100 \mathrm{~g}$ (solar dried) and $10.10 \mathrm{~g} / 100 \mathrm{~g}$ (sun dried) and Hibiscus esculentus are $18.50 \mathrm{~g} / 100 \mathrm{~g}$ (solar dried) and $10.90 \mathrm{~g} / 100 \mathrm{~g}$ (sun dried). The variation in the ash content might be attributed to the type of vegetable used, soil variation and maturity level of the vegetables (Table 2).

\section{Effect of iron content of the greens after dehydration}

In the present study, concentrated quantities of iron with multifold enhancement were observed in dehydrated form (Table 3). Cabinet dried green leafy vegetables showed higher iron content (ranged between 14.52 $86.80 \mathrm{mg} / 100 \mathrm{~g}$ ) as compared to other drying methods; whereas sun dried greens were found with lower iron contents. Iron content of sun dried and shade dried green leafy vegetables were in the range of $13.07-83.19 \mathrm{mg} / 100 \mathrm{~g}$ and $4.06-84.78 \mathrm{mg} / 100 \mathrm{~g}$ respectively. Green leafy vegetables dried in microwave oven exhibited similar iron content of $4.21-86.26$ $\mathrm{mg} / 100 \mathrm{~g}$ to the cabinet dried greens. Iron content was found highest in cabinet dried Amaranthus spinosus (86.80 $\mathrm{mg} / 100 \mathrm{~g})$ and lowest in sun dried Rumex vesicarius (3.94 $\mathrm{mg} / 100 \mathrm{~g}$ ). Singh et al., (2007) reported iron content of dehydrated bathua leaves as 27.48 $\mathrm{mg} / 100 \mathrm{~g}$, which was 6 times greater than the fresh values $(5.46 \mathrm{mg} / 100 \mathrm{~g})$. Nominally lower value of iron in the range of $23.87-25.30$ $\mathrm{mg} / 100 \mathrm{~g}$ was recorded in the present study. Joshi and Mehta (2010) studied the effect of dehydration on the nutritive value of drumstick leaves. Fresh drumstick leaves have an iron content of $0.085 \mathrm{mg} / 100 \mathrm{~g}$ whereas the iron content of the leaf powder prepared by different methods of dehydration (sun, shade and oven) was estimated to be $21 \mathrm{mg} / 100 \mathrm{~g}$ (sun dried), $24 \mathrm{mg} / 100 \mathrm{~g}$ (shadow dried) and $19 \mathrm{mg} / 100 \mathrm{~g}$ (oven dried) which was 95 to $96 \%$ more than their fresh counter parts.

\section{Effect of calcium content of the greens after dehydration}

In the present study, dehydration of green leafy vegetables leads to concentration of calcium by 4 to 5 folds. Cabinet dried green leafy vegetables were found with higher calcium content as compared to other drying methods; whereas sun dried green leafy vegetables showed lower calcium contents. In case of sun dried and shade dried greens, calcium content was ranged between 361.85 $2843.34 \mathrm{mg} / 100 \mathrm{~g}$ and 380.30 - 2886.43 $\mathrm{mg} / 100 \mathrm{~g}$ respectively. The calcium content of cabinet dried and microwave dried greens were at par which were in the range of 415.70 - $2920.38 \mathrm{mg} / 100 \mathrm{~g}$ and 4.09 - 2906.21 $\mathrm{mg} / 100 \mathrm{~g}$ respectively (Table 4 ). 
Table.1 Effect of moisture content $(\mathrm{g} / 100 \mathrm{~g})$ of the greens after dehydration

\begin{tabular}{|l|c|c|c|c|c|c|c|c|}
\hline \multicolumn{1}{|c|}{ Botanical Name } & \multicolumn{7}{c|}{ Moisture content (g/100g) } \\
\cline { 2 - 9 } & $\begin{array}{c}\text { Fresh } \\
\text { greens }\end{array}$ & $\begin{array}{c}\text { Sun } \\
\text { drying }\end{array}$ & $\begin{array}{c}\text { Shade } \\
\text { drying }\end{array}$ & $\begin{array}{c}\text { Cabinet } \\
\text { drying }\end{array}$ & $\begin{array}{c}\text { Microwave } \\
\text { drying }\end{array}$ & CD $_{(\mathbf{0 . 0 5})}$ & S.Ed \\
\hline Amaranthus spinosus & 85.39 & $4.30^{\mathrm{b}}$ & $5.63^{\mathrm{a}}$ & $3.90^{\mathrm{c}}$ & $3.72^{\mathrm{c}}$ & 0.26 & 0.11 \\
\hline Chenopodium album & 84.63 & $4.23^{\mathrm{b}}$ & $5.42^{\mathrm{a}}$ & $3.85^{\mathrm{c}}$ & $3.66^{\mathrm{c}}$ & 0.24 & 0.10 \\
\hline Spinaciaoleracea & 92.77 & $4.92^{\mathrm{b}}$ & $6.76^{\mathrm{a}}$ & $4.33^{\mathrm{c}}$ & $4.14^{\mathrm{c}}$ & 0.21 & 0.09 \\
\hline Phyllanthus amarus & 78.57 & $4.16^{\mathrm{b}}$ & $5.34^{\mathrm{a}}$ & $3.75^{\mathrm{c}}$ & $3.64^{\mathrm{c}}$ & 0.17 & 0.07 \\
\hline Talinum triangulare & 92.16 & $5.16^{\mathrm{b}}$ & $6.55^{\mathrm{a}}$ & $4.74^{\mathrm{c}}$ & $4.55^{\mathrm{c}}$ & 0.23 & 0.10 \\
\hline Ludwigiaadscendens & 87.23 & $4.82^{\mathrm{b}}$ & $6.35^{\mathrm{a}}$ & $4.34^{\mathrm{c}}$ & $4.24^{\mathrm{c}}$ & 0.17 & 0.07 \\
\hline
\end{tabular}

Table.2 Effect of ash content $(\mathrm{g} / 100 \mathrm{~g})$ of the greens after dehydration

\begin{tabular}{|l|c|c|c|c|c|c|c|}
\hline \multicolumn{1}{|c|}{ Botanical Name } & \multicolumn{7}{|c|}{ Ash content (g/100g) } \\
\cline { 2 - 9 } & $\begin{array}{c}\text { Fresh } \\
\text { greens }\end{array}$ & $\begin{array}{c}\text { Sun } \\
\text { drying }\end{array}$ & $\begin{array}{c}\text { Shade } \\
\text { drying }\end{array}$ & $\begin{array}{c}\text { Cabinet } \\
\text { drying }\end{array}$ & $\begin{array}{c}\text { Microwave } \\
\text { drying }\end{array}$ & $\begin{array}{c}\text { CD } \\
(\mathbf{0 . 0 5})\end{array}$ & S.Ed \\
\hline $\begin{array}{l}\text { Amaranthus } \\
\text { spinosus }\end{array}$ & 3.66 & $15.67^{\mathrm{c}}$ & $16.44^{\mathrm{b}}$ & $16.83^{\mathrm{a}}$ & $16.62^{\mathrm{a}}$ & 0.24 & 0.10 \\
\hline Chenopodium album & 2.56 & $10.12^{\mathrm{c}}$ & $10.76^{\mathrm{b}}$ & $11.56^{\mathrm{a}}$ & $11.35^{\mathrm{a}}$ & 0.22 & 0.09 \\
\hline Spinacia oleracea & 1.34 & $8.28^{\mathrm{c}}$ & $8.73^{\mathrm{b}}$ & $9.77^{\mathrm{a}}$ & $9.56^{\mathrm{a}}$ & 0.33 & 0.13 \\
\hline Phyllanthus amarus & 2.95 & $10.27^{\mathrm{c}}$ & $10.67^{\mathrm{b}}$ & $12.06^{\mathrm{a}}$ & $11.84^{\mathrm{a}}$ & 0.28 & 0.11 \\
\hline Talinum triangulare & 1.60 & $8.82^{\mathrm{c}}$ & $9.37^{\mathrm{b}}$ & $10.22^{\mathrm{a}}$ & $9.96^{\mathrm{a}}$ & 0.38 & 0.16 \\
\hline $\begin{array}{l}\text { Ludwigia } \\
\text { adscendens }\end{array}$ & 1.44 & $7.78^{\mathrm{c}}$ & $8.04^{\mathrm{b}}$ & $8.76^{\mathrm{a}}$ & $8.57^{\mathrm{a}}$ & 0.36 & 0.15 \\
\hline
\end{tabular}

Table.3 Effect of iron content $(\mathrm{mg} / 100 \mathrm{~g})$ of the greens after dehydration

\begin{tabular}{|l|c|c|c|c|c|c|c|}
\hline \multirow{2}{*}{ Botanical Name } & \multicolumn{7}{|c|}{ Iron content (mg/100g) } \\
\cline { 2 - 9 } & $\begin{array}{c}\text { Fresh } \\
\text { greens }\end{array}$ & $\begin{array}{c}\text { Sun } \\
\text { drying }\end{array}$ & $\begin{array}{c}\text { Shade } \\
\text { drying }\end{array}$ & $\begin{array}{c}\text { Cabinet } \\
\text { drying }\end{array}$ & $\begin{array}{c}\text { Microwave } \\
\text { drying }\end{array}$ & $\begin{array}{c}\text { CD } \\
(\mathbf{0 . 0 5})\end{array}$ & S.Ed \\
\hline $\begin{array}{l}\text { Amaranthus } \\
\text { spinosus }\end{array}$ & 20.49 & $83.19^{\mathrm{c}}$ & $84.78^{\mathrm{b}}$ & $86.80^{\mathrm{a}}$ & $86.26^{\mathrm{a}}$ & 0.58 & 0.25 \\
\hline Chenopodium album $^{*}$ & 4.45 & $23.87^{\mathrm{c}}$ & $24.66^{\mathrm{b}}$ & $25.30^{\mathrm{a}}$ & $25.14^{\mathrm{a}}$ & 0.18 & 0.08 \\
\hline Spinaciaoleracea & 2.38 & $13.07^{\mathrm{c}}$ & $13.88^{\mathrm{b}}$ & $14.52^{\mathrm{a}}$ & $14.24^{\mathrm{a}}$ & 0.24 & 0.09 \\
\hline Phyllanthus amarus & 12.52 & $31.12^{\mathrm{c}}$ & $31.65^{\mathrm{b}}$ & $32.50^{\mathrm{a}}$ & $32.21^{\mathrm{a}}$ & 0.33 & 0.13 \\
\hline Talinum triangulare & 4.34 & $25.36^{\mathrm{b}}$ & $25.48^{\mathrm{b}}$ & $28.20^{\mathrm{a}}$ & $27.95^{\mathrm{a}}$ & 0.31 & 0.12 \\
\hline Ludwigia adscendens & 4.08 & $15.85^{\mathrm{c}}$ & $16.23^{\mathrm{b}}$ & $17.46^{\mathrm{a}}$ & $17.21^{\mathrm{a}}$ & 0.24 & 0.09 \\
\hline
\end{tabular}


Table.4 Effect of calcium content $(\mathrm{mg} / 100 \mathrm{~g})$ of the greens after dehydration

\begin{tabular}{|l|c|c|c|c|c|c|c|}
\hline \multirow{2}{*}{ Botanical Name } & \multicolumn{7}{|c|}{ Calcium content (mg/100g) } \\
\cline { 2 - 9 } & $\begin{array}{l}\text { Fresh } \\
\text { greens }\end{array}$ & $\begin{array}{c}\text { Sun } \\
\text { drying }\end{array}$ & $\begin{array}{c}\text { Shade } \\
\text { drying }\end{array}$ & $\begin{array}{c}\text { Cabinet } \\
\text { drying }\end{array}$ & $\begin{array}{c}\text { Microwave } \\
\text { drying }\end{array}$ & $\begin{array}{c}\text { CD } \\
\text { (0.05) }\end{array}$ & S.Ed \\
\hline $\begin{array}{l}\text { Amaranthus } \\
\text { spinosus }\end{array}$ & 756.60 & $2843.34^{\mathrm{c}}$ & $2886.43^{\mathrm{b}}$ & $2920.38^{\mathrm{a}}$ & $2906.21^{\mathrm{a}}$ & 32.90 & 14.26 \\
\hline Chenopodium album $^{2}$ & 236.76 & $1062.32^{\mathrm{c}}$ & $1193.52^{\mathrm{b}}$ & $1142.50^{\mathrm{a}}$ & $1123.36^{\mathrm{a}}$ & 22.65 & 9.69 \\
\hline Spinacia oleracea & 74.57 & $418.23^{\mathrm{c}}$ & $434.77^{\mathrm{b}}$ & $494.66^{\mathrm{a}}$ & $488.24^{\mathrm{a}}$ & 16.64 & 7.21 \\
\hline Phyllanthus amarus & 142.60 & $336.70^{\mathrm{c}}$ & $378.32^{\mathrm{b}}$ & $405.70^{\mathrm{a}}$ & $398.76^{\mathrm{a}}$ & 11.37 & 4.93 \\
\hline Talinum triangulare & 227.26 & $1123.70^{\mathrm{c}}$ & $1176.54^{\mathrm{b}}$ & $1206.67^{\mathrm{a}}$ & $1186.92^{\mathrm{a}}$ & 26.31 & 11.40 \\
\hline Ludwigiaadscendens & 71.47 & $431.50^{\mathrm{c}}$ & $479.33^{\mathrm{b}}$ & $512.23^{\mathrm{a}}$ & $493.60^{\mathrm{a}}$ & 21.84 & 9.47 \\
\hline
\end{tabular}

Table.5 Effect of phosphorous content $(\mathrm{mg} / 100 \mathrm{~g})$ of the greens after dehydration

\begin{tabular}{|l|c|c|c|c|c|c|c|}
\hline \multicolumn{1}{|c|}{ Botanical Name } & \multicolumn{7}{|c|}{ Phosphorous content (mg/100g) } \\
\cline { 2 - 9 } & $\begin{array}{c}\text { Fresh } \\
\text { greens }\end{array}$ & $\begin{array}{c}\text { Sun } \\
\text { drying }\end{array}$ & $\begin{array}{c}\text { Shade } \\
\text { drying }\end{array}$ & $\begin{array}{c}\text { Cabinet } \\
\text { drying }\end{array}$ & $\begin{array}{c}\text { Microwave } \\
\text { drying }\end{array}$ & $\begin{array}{c}\text { CD } \\
(\mathbf{0 . 0 5})\end{array}$ & S.Ed \\
\hline Amaranthus spinosus & 56.26 & $187.40^{\mathrm{c}}$ & $198.67^{\mathrm{b}}$ & $223.80^{\mathrm{a}}$ & $212.78^{\mathrm{a}}$ & 11.73 & 5.08 \\
\hline Chenopodium album & 72.66 & $223.70^{\mathrm{c}}$ & $273.32^{\mathrm{b}}$ & $327.27^{\mathrm{a}}$ & $321.33^{\mathrm{a}}$ & 9.04 & 3.92 \\
\hline Spinacia oleracea & 26.29 & $126.45^{\mathrm{c}}$ & $155.20^{\mathrm{b}}$ & $176.66^{\mathrm{a}}$ & $168.23^{\mathrm{a}}$ & 9.28 & 4.02 \\
\hline Phyllanthus amarus & 24.41 & $65.63^{\mathrm{c}}$ & $76.30^{\mathrm{b}}$ & $82.40^{\mathrm{a}}$ & $79.87^{\mathrm{a}}$ & 5.72 & 2.48 \\
\hline Talinum triangulare & 112.35 & $487.80^{\mathrm{c}}$ & $496.30^{\mathrm{b}}$ & $546.56^{\mathrm{a}}$ & $534.20^{\mathrm{a}}$ & 15.52 & 6.37 \\
\hline Ludwigia adscendens & 43.65 & $332.20^{\mathrm{c}}$ & $356.31^{\mathrm{b}}$ & $382.50^{\mathrm{a}}$ & $375.70^{\mathrm{a}}$ & 10.23 & 4.43 \\
\hline
\end{tabular}

Table.6 Effect of potassium content $(\mathrm{mg} / 100 \mathrm{~g})$ of the greens after dehydration

\begin{tabular}{|l|c|c|c|c|c|c|c|}
\hline \multirow{2}{*}{ Botanical Name } & \multicolumn{7}{|c|}{ Potassium content (mg/100g) } \\
\cline { 2 - 9 } & $\begin{array}{c}\text { Fresh } \\
\text { greens }\end{array}$ & $\begin{array}{c}\text { Sun } \\
\text { drying }\end{array}$ & $\begin{array}{c}\text { Shade } \\
\text { drying }\end{array}$ & $\begin{array}{c}\text { Cabinet } \\
\text { drying }\end{array}$ & $\begin{array}{c}\text { Microwave } \\
\text { drying }\end{array}$ & $\begin{array}{c}\text { CD } \\
(\mathbf{0 . 0 5})\end{array}$ & S.Ed \\
\hline $\begin{array}{l}\text { Amaranthus } \\
\text { spinosus }\end{array}$ & 526.30 & $2348.40^{\mathrm{c}}$ & $2404.32^{\mathrm{b}}$ & $2442.70^{\mathrm{a}}$ & $2428.40^{\mathrm{a}}$ & 26.57 & 11.52 \\
\hline Chenopodium album $^{2}$ & 431.80 & $2033.12^{\mathrm{c}}$ & $2167.30^{\mathrm{b}}$ & $2215.64^{\mathrm{a}}$ & $2206.31^{\mathrm{a}}$ & 19.36 & 8.39 \\
\hline Spinacia oleracea & 535.80 & $2468.32^{\mathrm{c}}$ & $2508.90^{\mathrm{b}}$ & $2546.45^{\mathrm{a}}$ & $2526.30^{\mathrm{a}}$ & 23.26 & 10.07 \\
\hline Phyllanthus amarus & 211.03 & $985.82^{\mathrm{c}}$ & $1034.40^{\mathrm{b}}$ & $1078.38^{\mathrm{a}}$ & $1056.81^{\mathrm{a}}$ & 24.28 & 10.52 \\
\hline Talinum triangulare & 121.34 & $403.87^{\mathrm{c}}$ & $421.40^{\mathrm{b}}$ & $478.67^{\mathrm{a}}$ & $463.42^{\mathrm{a}}$ & 16.82 & 7.29 \\
\hline Ludwigia adscendens & 218.83 & $934.42^{\mathrm{c}}$ & $978.23^{\mathrm{b}}$ & $1039.37^{\mathrm{a}}$ & $1017.30^{\mathrm{a}}$ & 24.17 & 10.48 \\
\hline
\end{tabular}


Table.7 Effect of ascorbic acid content (mg/100g) of the greens after dehydration

\begin{tabular}{|l|c|c|c|c|c|c|c|}
\hline \multirow{2}{*}{ Botanical Name } & \multicolumn{7}{|c|}{ Ascorbic acid content (mg/100g) } \\
\cline { 2 - 9 } & $\begin{array}{c}\text { Fresh } \\
\text { greens }\end{array}$ & $\begin{array}{c}\text { Sun } \\
\text { drying }\end{array}$ & $\begin{array}{c}\text { Shade } \\
\text { drying }\end{array}$ & $\begin{array}{c}\text { Cabinet } \\
\text { drying }\end{array}$ & $\begin{array}{c}\text { Microwave } \\
\text { drying }\end{array}$ & $\begin{array}{c}\text { CD } \\
\text { (0.05) }\end{array}$ & S.Ed \\
\hline Amaranthus spinosus & 32.29 & $8.42^{\mathrm{d}}$ & $11.47^{\mathrm{a}}$ & $10.07^{\mathrm{c}}$ & $10.68^{\mathrm{b}}$ & 0.17 & 0.07 \\
\hline Chenopodium album & 23.73 & $5.05^{\mathrm{d}}$ & $6.74^{\mathrm{a}}$ & $5.33^{\mathrm{c}}$ & $5.56^{\mathrm{b}}$ & 0.15 & 0.06 \\
\hline Spinaciaoleracea & 26.67 & $5.73^{\mathrm{d}}$ & $10.06^{\mathrm{a}}$ & $7.54^{\mathrm{c}}$ & $8.75^{\mathrm{b}}$ & 0.16 & 0.07 \\
\hline Phyllanthus amarus & 32.17 & $9.65^{\mathrm{d}}$ & $13.53^{\mathrm{a}}$ & $10.04^{\mathrm{c}}$ & $10.58^{\mathrm{b}}$ & 0.14 & 0.06 \\
\hline Talinum triangulare & 44.37 & $8.74^{\mathrm{d}}$ & $11.34^{\mathrm{c}}$ & $12.48^{\mathrm{b}}$ & $13.96^{\mathrm{a}}$ & 0.12 & 0.05 \\
\hline Ludwigia adscendens & 17.34 & $1.32^{\mathrm{d}}$ & $3.94^{\mathrm{a}}$ & $3.24^{\mathrm{c}}$ & $3.76^{\mathrm{b}}$ & 0.15 & 0.06 \\
\hline
\end{tabular}

Calcium content was found highest in cabinet dried Amaranthus spinosus (2920.38 $\mathrm{mg} / 100 \mathrm{~g}$ ) and lowest in sun dried Phyllanthus amarus $(336.70 \mathrm{mg} / 100 \mathrm{~g})$. Calcium content of microwave dried and cabinet dried green leafy vegetables were on par, whereas sun dried and shade dried green leafy vegetables differ statistically. Rajeswari (2010) reported that the calcium content of selected green leafy vegetables under cabinet drying and microwave drying as amaranthus $296.14 \%$ (cabinet dried) and 293.92\% (microwave dried) and shepu $277.22 \%$ (cabinet dried) and $238.25 \%$ (microwave dried). Navale et al., (2014) also reported calcium content of fenugreek leaves as $1063 \mathrm{mg} / 100 \mathrm{~g}$ in open sun drying and $1753 \mathrm{mg} / 100 \mathrm{~g}$ in cabinet solar drying.

\section{Effect of phosphorous content of the greens after dehydration}

The dehydration process of green leafy vegetables leads to concentration of phosphorous by 3 to 4 folds. Cabinet dried green leafy vegetables showed higher phosphorous content as compared to other drying conditions; whereas sun dried greens showed lower phosphorous contents. Phosphorous content of cabinet dried and microwave dried greens have no statistical difference which were in the range of $82.40-$ $546.56 \mathrm{mg} / 100 \mathrm{~g}$ (cabinet dried) and 79.87 $534.20 \mathrm{mg} / 100 \mathrm{~g}$ (microwave dried). Sun dried and shade dried green leafy vegetables exhibited phosphorous content in the range of $65.63-487.80 \mathrm{mg} / 100 \mathrm{~g}$ and $76.30-496.30$ $\mathrm{mg} / 100 \mathrm{~g}$ respectively. Phosphorous content was found highest in cabinet dried Talinum triangulare $(546.56 \mathrm{mg} / 100 \mathrm{~g}$ ) and lowest in sun dried Phyllanthus amarus $(65.63 \mathrm{mg} / 100 \mathrm{~g})$ (Table 5). Kowsalya and Vidhya (2004) reported that the phosphorous content of selected fresh green leaves of Amaranthus dubius, Amaranthus spinosus, Portulaca oleraceae and drumstick leaves was $54.75 \mathrm{mg} / 100 \mathrm{~g}, \quad 41 \mathrm{mg} / 100 \mathrm{~g}, 39.25$ $\mathrm{mg} / 100 \mathrm{~g}$ and $71.50 \mathrm{mg} / 100 \mathrm{~g}$ respectively. On dehydration, the phosphorus content increased however, maximum increment was observed by cabinet drying technique. The result of the present study showed significantly higher values of phosphorous for cabinet dried green leafy vegetables than sun and shade dried green leafy vegetables. The slight variation in phosphorous content observed between cabinet and microwave oven dried green leafy vegetables were not statistically significant.

\section{Effect of potassium content of the greens after dehydration}

In the present study, cabinet dried green leafy vegetables were found with higher potassium content as compared to other drying methods; whereas sun dried greens showed lower potassium contents. Potassium content was found highest in cabinet dried 
Spinaciaoleracea (2546.45 mg/100g) and lowest in sun dried Talinum triangulare $(403.87 \mathrm{mg} / 100 \mathrm{~g})$. The potassium content of cabinet dried and microwave dried greens were at par and ranged from $478.67-2546.45$ $\mathrm{mg} / 100 \mathrm{~g}$ and 463.42 - $2526.30 \mathrm{mg} / 100 \mathrm{~g}$ respectively. The potassium content of sun dried and shade dried greens was in the range of $403.87-2468.32 \mathrm{mg} / 100 \mathrm{~g}$ and $421.40-$ $2508.90 \mathrm{mg} / 100 \mathrm{~g}$ respectively. Sun dried greens exhibited significant lower level of potassium. This observation may probably be due to potassium being cationic element that does not polarize easily in heating but forms oxides when exposed to light and air.

Liman et al., (2014) reported the potassium content of drumstick leaves in sun dried (8.83 $\mathrm{mg} / 100 \mathrm{~g})$, oven dried sample $(8.50 \mathrm{mg} / 100 \mathrm{~g})$ and samples dried in moisture analyzer (7.83 $\mathrm{mg} / 100 \mathrm{~g}$ ). As for bitter leaf (Vernonia amygdalina), potassium content is found in oven dried sample with $20.58 \mathrm{mg} / 100 \mathrm{~g}$ followed by that for sun dried sample with $20.08 \mathrm{mg} / 100 \mathrm{~g}$ then the least is seen for moisture analyzer with $18.92 \mathrm{mg} / 100 \mathrm{~g}$ (Table $6)$.

\section{Effect of ascorbic acid content of the greens after dehydration}

From the Table 7, it can be seen that ascorbic acid was found reduced during different drying methods as compared to fresh condition. Ascorbic acid is a heat labile water soluble vitamin which decreases in heat treatment. Sun drying caused maximum loss in ascorbic acid and shade dried samples showed better retention of ascorbic acid which may be due to absence of heat treatment. Ascorbic acid of sun dried and shade dried greens were in the range of $0.58-$ $9.87 \mathrm{mg} / 100 \mathrm{~g}$ and 2.16 - $13.87 \mathrm{mg} / 100 \mathrm{~g}$ respectively. After shade drying, microwave dried greens showed good retention of ascorbic acid (ranged between $2.02-13.96$ mg/100g). Talinum triangulare showed exception as microwave dried and cabinet dried sample showed better retention than shade drying which may be due to longer duration of shade drying causing loss of nutrients. Mehta (2014) reported the ascorbic acid content of Daucuscarota and Brassica olerecea leaves to be $69.84 \mathrm{mg} / 100 \mathrm{~g}$ and 7.32 $\mathrm{mg} / 100 \mathrm{~g}$ in fresh sample. The ascorbic acid content of Daucuscarota was decreased to $42.65 \mathrm{mg} / 100 \mathrm{~g}$ and in Brassicaolerecea to $5.62 \mathrm{mg} / 100 \mathrm{~g}$ in oven dehydrated sample. Results suggested that after processing, there was a reduction in ascorbic acid content in comparison with their fresh counterparts. Per cent decrement of both the processed samples, prepared by Daucus carota and Brassica olerecea was approximately 20 to 50 per cent.

Sakhale and Pawar (2007) studied dehydration of curry leaves and reported that the percent ascorbic acid content $f$ tray dried curry leaves decreased significantly indifferent drying conditions. The percent retention of ascorbic acid was found maximum in tray-dried leaves $(46.42 \%)$ whereas minimum in sun drying method $(28.57 \%)$. This decrease might have been because of oxidation of ascorbic acid during dehydration. The decrease in vitamin and mineral contents during processing has also been noted earlier by Ranganath and Dubash (1981) and Singh et al., (2003). The exposure of the green leafy vegetables to direct sunlight resulted in highest loss in ascorbic acid content as compared to shade, tray and microwave drying. This is associated with high sensitivity of ascorbic acid to most assessable atmospheric constituents like oxygen, light and temperature. The maximum retention of ascorbic acid in tray dried greens may be due to controlled drying conditions and least exposure of vegetables to temperature and air (Goyal and Mathew, 1990). Green leafy vegetables are treasure trove of micronutrients. Judicious 
combination of green leafy vegetables might serve as richer source of specific micronutrients. Dehydrated green leafy vegetables will serve as an instant food ingredient to be used without laborious preprocessing. Dehydration also increases shelflife of the greens. Dehydrated green leafy vegetables can be efficiently utilized for processing of value added products. Consumption of dehydrated green leafy vegetables incorporated products in daily diet will ensure micronutrient security.

\section{References}

A.O.A.C. Official Methods of Analysis. Association of Official Analytical Chemists $\left(17^{\text {th }}\right.$ ed.) Washington D.C. (2000).

A.O.A.C. Official methods of Analysis of the Association of Official Analysis Chemists, Washington D.C., (1984).

Fathima A, Begum K, and Rajalakshmi D, Microwave Drying of selected greens and their sensory characteristics. Plant Fd. Human Nutr. (2001) 56: 303-311.

Goyal M, and Mathew S, Physico-chemical characteristics of cauliflower dried under different drying conditions. $J$. Nutr. Dietet. (1990) 27(2):39.

Gupta S. and Prakash J, Nutritional and sensory quality of micronutrient rich traditional products incorporated with greenleafy vegetables. Intern. Food Res. J. (2011)18: 667-675.

Joshi P, and Mathur B, Preparation of value added products from the leaf powders of dehydrated less utilized green leafy vegetables. J. Hort. Forestry. (2010) 2(9): 223-228.

Joshi P, and Mehta D, Effect of dehydration on the nutritive value of drumstick leaves. J. Metabol. Sys. Biol.(2010)1: 59.

Kowsalya S, and Vidhya MR, Nutritive value of selected dehydrated green leafy vegetables. Indian J. Nutr. Dietet. (2004) 41: 279-286.

Kushwaha S. Comparative Effect of Cabinet, Microwave and Freeze Drying On Physical and Nutritional Quality of Onion Stalks. Asian J.Exp.Biol.Sci. (2012)3(3): 531-535.

Liman MG, Abdullah AS, Maigoro AL and Umar KJ, Effects of Three Drying Techniques on Mineral Composition of Some Leafy Garden Vegetables. IOSR J. Appl. Chem. (2014)7(1):38-42.

Mehta D, Effect of Processing on Nutrient Composition of Selected Green Leafy Vegetables and Development of Value Added Products. Ph.D (H.Sc.) Thesis. IIS University, Jaipur (2014).

Nwufo MI, Effects of water stress on the postharvest quality of two leafy vegetables, Telfairia occidentalis and Pterocarpus soyauxii during storage. J. Sci. Food Agric. (1994) 64: 265-269.

Rajeswari R, Dehydration of Green Leafy Vegetables and Its Effect on Quality. M.Sc. (H.Sc.) Thesis. University of Agricultural Sciences, Dharwad 580005(2010).

Ranganath DR and Dubash PJ, Loss of color and vitamins on dehydration of vegetables. Indian Food Packer, pp. (1981)4-10.

Ranganna, S. Hand book of analysis and quality control for fruit and vegetable products. $2^{\text {nd }}$ Ed., Tata McGraw-Hill, New Delhi, India. (1986).

Sakhale BK, and Pawar VN, Studies on Effect of Drying Modes on Quality of Dehydrated Cabbage. Jurnal. Teknol. Dan Indust. Pangan. (2007)18(1): 5558.

Singh G, Kawatra A, Sehgal S, and Pragati, Effect of storage on nutritional composition of selected dehydrated green leafy vegetable powders. Plant Fd. Hum. Nutr. (2003) 58: 1-9. 
Singh L, Yadav N, KumarAR, GuptaAK, Chacko J, Pravin K, and Tripathi U, Preparation of value added products from dehydrated bathua leaves (Chenopodium album Linn). Nat. Prod. Radian. (2007)6: 6-10.

Ukegbu PO, and Okereke CJ, Effect of solar and sundrying methods on the nutrient composition and microbial load in selected vegetables, African spinach (Amaranthus hybridus), fluted pumpkin (Telferia occindentalis) and Okra (Hibiscus esculentus). Sky J. FoodSci. (2013). 2(5): 35-40.

\section{How to cite this article:}

Sushmita Khatoniar, Mridula Saikia Barooah and Mamoni Das. 2019. Effect of Different Drying Methods on Micronutrient Content of Selected Green Leafy Vegetables. Int.J.Curr.Microbiol.App.Sci. 8(07): 1317-1325. doi: https://doi.org/10.20546/ijcmas.2019.807.156 